\title{
Another breakthrough in power supply technology - lithium-ion batteries: 2019 Nobel Prize winners in chemistry John Goodenough, Stanley Whittingham and Akira Yoshino
}

\author{
Vyacheslav M. Tyutyunnik $\bowtie$ \\ Tambov State Technical University, 106, Sovetskaya St., Tambov 392000, Russian Federation, \\ International Nobel Information Centre (INIC), 30-6, Pervomaiskaya Sq., Tambov 392002, Russian Federation
}

$\bowtie$ vmtyutyunnik@gmail.com

\begin{abstract}
In 2019, the Nobel Prize in Chemistry was awarded to the creators of lithium-ion batteries, who over the past half century have literally revolutionized the battery power supply. The prize was shared equally by American physicist and materials expert John Bannister Goodenough, British-American chemist Michael Stanley Whittingham and Japanese process chemist Akira Yoshino. The operation of lithium-ion batteries is based on the electrochemical oxidation reactions of lithium metal, which is part of the anode. When discharged, lithium is oxidized and its cation moves to the cathode; when charged, under the action of the applied electrical voltage, lithium cations move to the anode, where the recovery occurs. The biographies of the laureates and their main achievements are described briefly. Lithium-ion batteries are produced in huge quantities and have created another breakthrough in energy supply technology.
\end{abstract}

Keywords: lithium-ion batteries; power supply technologies; 2019 Nobel Prize winners in chemistry John Bannister Goodenough, Michael Stanley Whittingham and Akira Yoshino.

For citation: Tyutyunnik VM. Another breakthrough in power supply technology - lithium-ion batteries: 2019 Nobel Prize winners in chemistry John Goodenough, Stanley Whittingham and Akira Yoshino. Journal of Advanced Materials and Technologies. 2021;6(3):163-166. DOI: 10.17277/jamt.2021.03.pp.163-166

\section{Очередной прорыв в технологии энергоснабжения - литий-ионные батареи: лауреаты Нобелевской премии по химии 2019 года Джон Гуденаф, Стэнли Уиттингем и Акира Йошино}

\author{
В. М. Тютюнник \\ Тамбовский государственный технический университет, \\ ул. Советская, 106, Тамбов 392000, Российская Федерация, \\ Международный Информаџионный Нобелевский Центр (МИНЦ), \\ Первомайская площадь, 30-6, Тамбов 392002, Российская Федерачия
}

$\bowtie$ vmtyutyunnik@gmail.com

\begin{abstract}
Аннотация: В 2019 году Нобелевская премия по химии увенчала создателей литий-ионных батарей, которые за прошедшие полвека буквально революционизировали аккумуляторное энергоснабжение. Премию разделили поровну американский физик и материаловед Джон Баннистер Гуденаф, британо-американский химик Майкл Стэнли Уиттингем и японский химик-технолог Акира Йошино. Работа литий-ионных аккумуляторов основана на электрохимических реакциях окисления металлического лития, который входит в состав анода. При разрядке литий окисляется и его катион движется к катоду, а при зарядке, наоборот: под действием приложенного электрического напряжения катионы лития перемещаются к аноду, где происходит восстановление. Даны краткие биографии лауреатов и их основные достижения. Литий-ионные батареи производятся в огромных количествах и создали очередной прорыв в технологии энергоснабжения.
\end{abstract}

Ключевые слова: литий-ионные батареи; технологии энергоснабжения; лауреаты Нобелевской премии по химии 2019 года Джон Баннистер Гуденаф, Майкл Стэнли Уиттингем и Акира Йошино.

Для цитирования: Tyutyunnik VM. Another breakthrough in power supply technology - lithium-ion batteries: 2019 Nobel Prize winners in chemistry John Goodenough, Stanley Whittingham and Akira Yoshino. Journal of Advanced Materials and Technologies. 2021;6(3):163-166. DOI: 10.17277/jamt.2021.03.pp.163-166 
The problem of renewable energy sources is one of the central problems in modern power engineering. Over the past century, a lot of scientific research, technologies and techniques in the field of energy production and storage have been developed [1-4]. Finally, in 2019, the Nobel Prize in Chemistry was awarded to the creators of lithium-ion batteries that have literally revolutionized our life over the past half century. The prize was awarded to the American physicist and materials scientist John Bannister Goodenough (born July 25, 1922), the BritishAmerican chemist Michael Stanley Whittingham (born December 22, 1941), and the Japanese chemical technologist Akira Yoshino (born January 30, 1948) [5].

The lithium-ion batteries operate on electrochemical oxidation reactions of metallic lithium, which is part of the anode. When discharged, lithium is oxidized and its cation moves to the cathode; when charged, under the action of the applied electrical voltage, lithium cations move to the anode, where the recovery occurs. This is how they fundamentally differ from lead-acid batteries, in which new chemical compounds are formed when energy is stored, i.e. the structure of the electrode material changes. In addition, lithium-ion batteries are lighter, more compact and more energy-intensive. If the capacity of a lead-acid battery is $30-40 \mathrm{~W} \cdot \mathrm{h}$ per kilogram of the device, then a lithium-ion battery is more than $250 \mathrm{~W} \cdot \mathrm{h}$ per kilogram. The development of lithium-ion batteries began in the 1970s and 1980s and was stimulated by the oil crisis. The main task was the choice of materials for the battery cathode.

Goodenough was born to American parents in Jena, Germany. He received his Bachelor's degree in mathematics, Master's and Ph.D. from Yale University in the 1940s, and but he earned his Ph.D. in physics at the University of Chicago in 1952. At the beginning of his scientific career in the Lincoln Laboratory of the Massachusetts Institute of Technology, he laid the foundation for the development of random access memory for computers. From 1976-1986 he worked as a professor and director of the Laboratory of Inorganic Chemistry at the University of Oxford. In 1979, he showed that by using lithium cobalt oxide $\mathrm{LiCoO}_{2}$ as the cathode of a lithium-ion rechargeable battery, a high stored energy density could be achieved with an anode other than metallic lithium. This discovery paved the way for the development of lithium-ion batteries, which are now ubiquitous around the world for mobile phones, power tools, laptops, tablets and other wireless devices, as well as electric and hybrid vehicles.
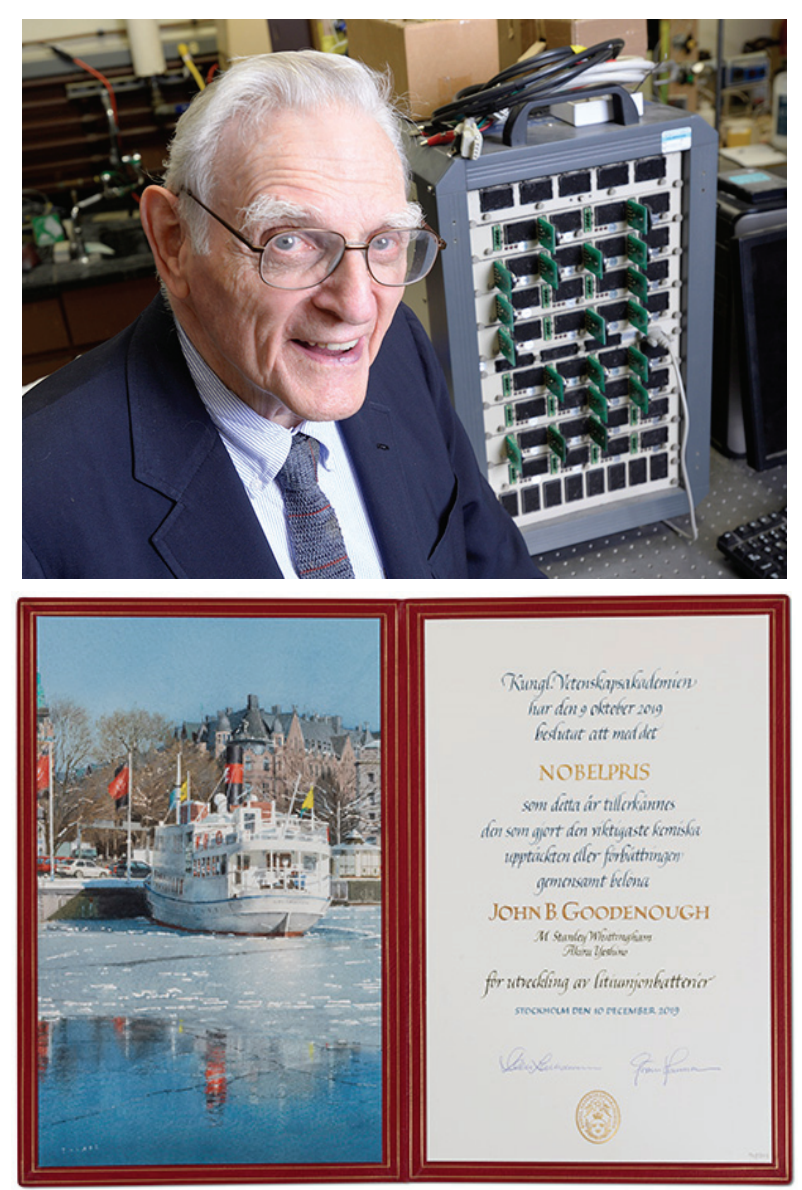

\section{J. Goodenough in his laboratory and his Nobel diploma (C NobelPrize.org)}

From 1986, Goodenough worked as a professor in the Department of Mechanical Engineering at the Cochrell School and in the Department of Electrical and Computer Engineering; despite the approaching century (he is the oldest Nobel laureate ever awarded at 97), he chaired the Virginia H. Cockrell Centennial Chair in Engineering at the University of Texas at Austin, USA. He is the author of eight books and over 800 journal articles [6] and has received numerous national and international awards. The experts from Chemical \& Engineering News predicted the Goodenough Nobel Prize in 2019 and the authors of Inside Science - in 2018.

Whittingham was born in Nottingham, UK, attended Oxford University and received his doctorate there in 1968. After completing his second doctorate from Stanford University, USA, he worked for the oil companies Exxon and Schlumberger, and in 1988 became a professor at New York State University at Binghamton. $\mathrm{He}$ is currently Distinguished Professor of Chemistry and Chief of Chemistry at the Northeast Center for Chemical Energy Storage (NECCES) of the US Department of Energy in Binghamton. 

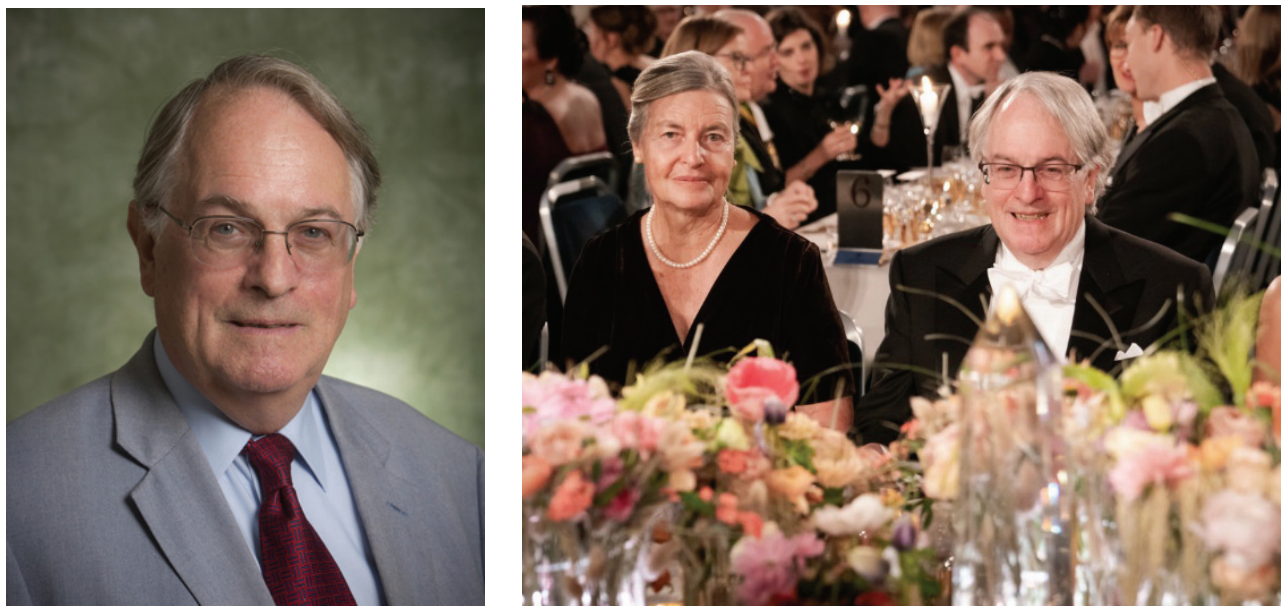

S. Whittingham; he and the wife of M. Major, the laureate in physics at the Nobel banquet on December $10,2019$. (C) NobelMedia)
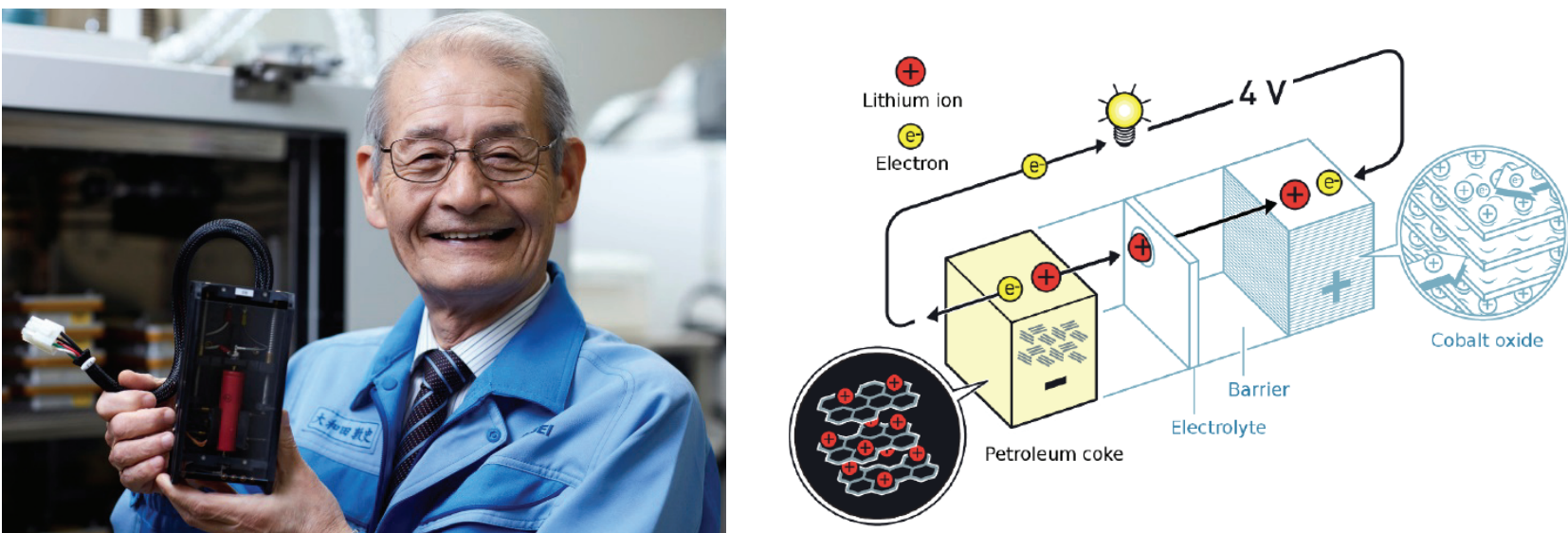

Yoshino with a lithium-ion battery; movement of ions in a lithium-ion battery [9]

Back in the early 1970s, Whittingham created a working lithium battery, but it was explosive due to the use of lithium metal from which the battery anode was made. The cathode was made of titanium disulfide $\mathrm{TiS}_{2}$. Strictly speaking, this was not a lithium-ion battery, but it was the first example of the use of a material that intercalates lithium into its structure during discharge. Currently, his research interests are related to the production and chemical and physical properties of new inorganic oxide materials for improved energy storage [7]. They recently discovered the crucial role that singlephase reactions play in discharging battery electrodes.

Yoshino was born in Suita, Japan. He was educated as a process engineer at the University of Kyoto, since 1972 he has been working for the chemical company Asahi Kasei since 1972, where he has been heading his own laboratory since 2005 . He received his doctorate from Osaka University in 2005 and has been a professor at Meijou University in Nagoya since 2017. In 1985, he developed a battery with a polyacetylene anode and a lithium cobaltite cathode $\mathrm{LiCoO}_{2}$. It was the first commercially viable lithium-ion battery to be patented [8]. If we assume that the Japanese Sony Corporation released the first commercial product in 1991, the lithium-ion batteries are already 30 years old.

The total production of lithium-ion batteries by 2023, according to Benchmark Minerals, could reach 1,000 GWh (20 million electric vehicles). The market volume, according to the analytical agency Market Research Engine, will exceed \$ 92 billion by 2024, while today it is about $\$ 40$ billion. Yet, in Russia, lithium-ion batteries are produced only at the Novosibirsk Liotech plant with a design capacity $1 \mathrm{GWh}$ per year.

This research received no external funding.

The authors declare no conflict of interest.

\section{References}

1. Tyutyunnik VM. Scientometric analyses of nominations for Nobel Prizes. 4. Nominees and nominators for the Nobel Prize in Chemistry, 1911-1950. Istoriya nauki $i$ 
tekhniki = History of Science and Technology. 2021;2:12-38. DOI:10.25791/intstg.2.2021.1254 (In Russ.)

2. Tyutyunnik VM. Nomination for the Nobel Prize in Physics in 1911-1950. Prikladnaya fiszika $i$ matematika $=$ Applied Physics and Mathematics. 2021;1:3-26. DOI:10.25791/pfim.01.2021.1189 (In Russ.)

3. Tyutyunnik VM. Graphene breakthrough into future technology: the 2010 Nobel Prize in Physics Laureate Sir Konstantin Sergeevich Novoselov. Journal of Advanced Materials and Technologies. 2021;6(1):6-9. DOI:10.17277/jamt.2021.01.pp.006-009

4. Tyutyunnik VM. Generation of high-intensity ultrashort optical pulses: 2018 Nobel Prize winners in Physics Gerard Mourou and Donna Strickland. Journal of Advanced Materials and Technologies. 2021;6(2):87-90. DOI:10.17277/jamt.2021.02.pp.087-090
5. The Nobel Prize in Chemistry 2019. Available from: https:/www.nobelprize.org/prizes/chemistry/2019/ summary/ [Accessed 17 July, 2021]

6. Huang K, Goodenough JB. Solid Oxide Fuel Cell Technology: Principles, Performance and Operations. Woodhead Publishing; 2009. 340 p.

7. Whittingham MS. Lithium batteries and cathode materials. Chemical Review. 2004;104:4271-4301.

8. Yoshino A, Sanechika K, Nakajima T. Secondary battery. United States patent 4,668,595A May 10, 1985.

9. Ramström O. Lithium-ion batteries. Scientific Background on the Nobel Prize in Chemistry 2019. Available from: https:/www.nobelprize.org/uploads/ 2019/10/advanced-chemistryprize2019-2.pdf [Accessed 17 July, 2021]

\section{Информация об авторах / Information about the authors}

Тютюнник Вячеслав Михайлович, доктор технических наук, профессор, ФГБОУ ВО «Тамбовский государственный технический университет»; генеральный директор, Международный Информационный Нобелевский Центр, Тамбов, Российская Федерация; ORCID 0000-0002-2099-5730; e-mail: vmtyutyunnik@gmail.com
Vyacheslav M. Tyutyunnik, D. Sc. (Engineering), Professor, Tambov State Technical University; Director General, International Nobel Information Centre, Tambov, Russian Federation; ORCID 0000-0002-20995730; e-mail: vmtyutyunnik@gmail.com 